\title{
Phytochemical constituent and antioxidant activity of Thaumatococcus daniellii Benn (Benth.) leaves (food wrapper)
}

\author{
Oke Ibukunoluwa Ayodeji ${ }^{1, a}$, Olufemi Adeleye ${ }^{2, b}$, Oluwagbenga Dada ${ }^{1, c}$, \\ Olaoluwa Adeyemi ${ }^{1, d}$, God'swill N. Anyasor ${ }^{1, \mathrm{e}^{*}}$
}

\author{
${ }^{1}$ Department of Biochemistry, Benjamin S. Carson (Snr.) School of Medicine, Babcock University, \\ Ilisan Remo, Ogun State, Nigeria, PMB 21244 Ikeja. \\ ${ }^{2}$ College of Postgraduate Studies, Babcock University, Ilisan Remo, Ogun State, Nigeria, PMB \\ 21244 lkeja. \\ aokeibuku@yahoo.com, badeleyeo@babcock.edu.ng, 'dasmi4all@yahoo.com, \\ olaoluwatemi@yahoo.com, eanyasorg@babcock.edu.ng
}

\section{Keywords: Antioxidant; Food wrapper; Leaves; Phytochemical; Thaumatococcus daniellii}

\begin{abstract}
Thaumatoccocus daniellii Benn (Benth.) is an organic food wrapper that influences the color and flavour of most foods processed and packaged with it. Hence, this study was designed to evaluate the phytochemical constituent and antioxidant activity of $T$. daniellii leave. Quantitative phytochemical analysis was carried out using standard procedures while antioxidant activity was assayed using 2',2'diphenylpicrylhydrazine (DPPH) and ferric ion reducing antioxidant potential (FRAP). Results showed that $T$. daniellii leaves contained flavonoids, polyphenols, alkaloids and saponins. Furthermore, aqueous leaf fraction had higher quantity of polyphenols $(0.41 \pm 0.1 \mathrm{mg} \%$ gallic acid) and flavonoids $(0.28 \pm 0.1 \mathrm{mg} \%$ quercetin) than polyphenols $(0.23 \pm 0.3 \mathrm{mg} \%$ gallic acid) and flavonoids $(0.11 \pm 0.1 \mathrm{mg} \%$ quercetin $)$ in hexane leaf fraction. Investigation of antioxidant activity revealed that $100-500 \mathrm{mg} / \mathrm{ml}$ aqueous leaf fraction exhibited a significantly $(\mathrm{P}<0.05)$ higher DPPH radical scavenging activity than the hexane leaf fraction. In addition, the aqueous fraction of $T$. daniellii leaves exhibited a significantly $(\mathrm{P}<0.05)$ higher ferric ion reducing potential than hexane leaf fraction. Thus, data from this study indicated that $T$. daniellii leaves color and flavour enhancing properties could be attributed to the presence of polyphenols and flavonoids. In addition, its use as food wrapper may introduce phyto-antioxidants into foods processed and packaged with $T$. daniellii leaves.
\end{abstract}

\section{Introduction}

Antioxidants are known to act as first line of defence in the body against free radical-induced oxidative cell damage [1]. Some antioxidants could act independently or as a network to stabilize free radicals, pro-oxidant metals and terminate deleterious chain reactions elicited by free radicals [2]. Phyto-antioxidants have been reported to be present in sundry parts of plant including vegetables and fruits [3].

Dietary antioxidants act by controlling free radical level with a corresponding decrease in the symptoms of oxidative stress [4]. This notion has led to an increased demand for replacement of synthetic additives by food industry with phyto-antioxidants due to its presumed safety and several therapeutic applications [5,6].

Thaumatococcus daniellii Benn (Benth.) of Maranthaceae family is commonly known as "sweet prayers plant" [7]. It is a rhizomatous, perennial and monocotyledonous plant located in tropical rain forests and coastal areas of Nigeria, Ghana, Cote d'Ivoire, Princes Island, Uganda and Indonesia [8]. T. daniellii has a long and slender stalks that grows up to $2-3 \mathrm{~m}$ high, each bearing a single tough and ovoid shaped leaf. These leaves vary in sizes depending on the plant's age and habitat [7]. 
T. daniellii leaves, stalk, fruits and rhizomes contribute to the economy of rural people in Southern Nigeria and globally [9]. Furthermore, the gobal prominence of $T$. danielli resulted from the discovery of thaumatin [9]. Thaumatin is a non-caloric sweetener and taste modifier that has been reported to be 1600 times sweeter than sucrose [10]. T. daniellii leaves which is locally known as katemfe or ewe in Nigeria, is mostly used as food wrapper by local food industry while the petiole is used to weave mats and as building material [11]. In ethnomedical practice, the sap of $T$. daniellii leaf stalk is used as sedative and antidote against venoms, stings and bites while its root sap is used for the treatment of mental retardation [12].

In some part of United States and South America, the use of T. daniellii leaves as food wrapper has gained wide acceptance due to its exotic and flavour enhancing property [13]. The leaves have large surface areas to wrap large amount of food [14]. However, most literatures on $T$. daniellii were focused on thaumatin with paucity of scientific validation of $T$. daniellii leaves as food colorant, flavour enhancer and also as phytomedicine. Thus, this study was designed to evaluate the phytochemical constituent and antioxidant activity of $T$. daniellii_leaves to proffer a scientific rationale for the use of $T$. daniellii leaves as food wrappers with ethnomedical benefits.

\section{Materials and methods}

\section{Collection of plant material}

Fresh leaves of Thaumatococcus daniellii were purchased from a local market at Ilisan Remo, Ogun State, Nigeria in January 2015.

\section{Extract preparation}

T. daniellii leaves were washed and oven dried at $35^{\circ} \mathrm{C}$ for $48 \mathrm{~h}$. Dried $T$. daniellii leaves were pulverized using electric blender. Pulverized sample $(57.14 \mathrm{~g})$ were soaked in $400 \mathrm{ml} 70 \%$ methanol for $48 \mathrm{~h}$ with intermittent shaking. The suspension was filtered using Whatman No. 1 filter paper and concentrated in a rotary evaporator (Buchi Rotavapor RE, Switzrland) at $30^{\circ} \mathrm{C}$. The concentrated extract obtained was reconstituted in distilled water and subsequently partitioned using $\mathrm{n}$-hexane in 1:2 v/v with separating funnel. Hexane fraction and the remaining fraction considered as aqueous fractions were concentrated at $30^{\circ} \mathrm{C}$. The two fractions obtained were stored in the refrigerator at $4^{\circ} \mathrm{C}$ until further use.

\section{Quantitative phytochemical analysis}

\section{Estimation of total phenolic content}

Folin-Ciocalteau colorimetric method as described by Ghasemi et al. [15] was used to determine total polyphenol content. Standard gallic acid solution, hexane and aqueous fractions of $T$. daniellii leaves $(0.1-0.5 \mathrm{ml} ; 1 \mathrm{mg} / \mathrm{ml})$ were pipetted separately into test tubes. Folin-Ciocalteau reagent $(5$ $\mathrm{ml}$ ) was added to each test tubes which was allowed to stand for $5 \mathrm{~min}$ followed by the addition of 4 $\mathrm{ml} 1 \mathrm{M} \mathrm{Na} \mathrm{CO}_{3}$ and made up to $10 \mathrm{ml}$ with distilled water. All tubes were allowed to stand for 15 min. The absorbance of reaction mixture was measured against reagent blank at $765 \mathrm{~nm}$ using UVvisible Schimadzu Spectrophotometer. Polyphenol content of fractions was calculated as $\mathrm{mg} \%$ gallic acid equivalent using the equation from the standard phenol calibration curve.

\section{Estimation of total flavonoid content}

Complex aluminium chloride method for determination of total flavonoids as described by Ordonez et al. [16] was used to determine total flavonoid content. Standard quercetin solution, hexane and aqueous fractions of $T$. daniellii leaves $(0.1-0.5 \mathrm{ml} ; 1 \mathrm{mg} / \mathrm{ml})$ were taken separately into test tubes followed by the addition of $0.5 \mathrm{ml} 2 \% \mathrm{AlCl}_{3}$ prepared in ethanol and made up to $5 \mathrm{ml}$ with distilled water. All tubes were allowed to stand for $60 \mathrm{~min}$ at room temperature. Absorbance was measured at $420 \mathrm{~nm}$ using UV-visible Schimadzu Spectrophotometer. Total flavonoid content was expressed as $\mathrm{mg} / \mathrm{g}$ quercetin equivalent using the equation from the standard flavonoid calibration curve. 


\section{Determination of saponin content}

Saponin content was carried out using the method described by Okwu and Josiah [17]. Pulverized T. daniellii sample ( $5 \mathrm{~g}$ ) was dispersed in $50 \mathrm{ml} 20 \% \mathrm{v} / \mathrm{v}$ ethanol and the suspension heated over a hot water bath for $1 \mathrm{~h}$ with continuous stirring at $55^{\circ} \mathrm{C}$. The mixture was filtered and the residue reextracted with another $50 \mathrm{ml} \mathrm{20 \%}$ ethanol. Combined extracts were reduced to $20 \mathrm{ml}$ over a hot water bath at $90^{\circ} \mathrm{C}$. The concentrate was vigorously mixed with $10 \mathrm{ml}$ diethyl ether in $250 \mathrm{ml}$ separating funnel and aqueous layer was collected while ether layer was discarded. Butan-1-ol (20 $\mathrm{ml}$ ) was added to the aqueous layer and subsequently washed three times with $10 \mathrm{ml} \mathrm{5 \%} \mathrm{w/v}$ sodium chloride. The mixture was heated to dryness on a hot water bath and further oven dried to a constant weight.

Percentage saponin content was calculated thus:

$$
\% \text { Saponin }=\frac{\text { Weight of final extract }}{\text { Weight of sample }} \times 100
$$

\section{Determination of alkaloid content}

Alkaloid content of the plant sample was determined using the method described by Onyilagba and Islam [18]. Pulverized sample (5 g) of T. daniellii leaves was weighed into $250 \mathrm{ml}$ beaker and 200 $\mathrm{ml}$ of $20 \%$ acetic acid in ethanol was added and allowed to stand for $4 \mathrm{~h}$. The suspension was filtered and concentrated to one-quarter of its original volume using a hot water bath at $100^{\circ} \mathrm{C}$. Concentrated ammonium hydroxide was added drop wise to the filtrate until complete precipitation. The precipitates were washed with dilute ammonium hydroxide and subsequently filtered to obtained residue which was dried and weighed.

Alkaloid content was determined using the formula below:

$$
\% \text { Alkaloid }=\frac{\text { Final weight of sample }}{\text { Initial weight of sample }} \times 100
$$

\section{Determination of antioxidant activities in vitro}

\section{DPPH free radical scavenging assay}

Free radical scavenging activity of hexane and aqueous fractions of $T$. daniellii leaf was carried out according to spectrophotometric method described by Mensor et al. [19]. One $\mathrm{ml}$ of a $0.3 \mathrm{mM}$ DPPH methanol solution was added to either $2.5 \mathrm{ml}$ hexane or aqueous fractions $(100-500 \mu \mathrm{g} / \mathrm{ml})$ and allowed to react at room temperature for $30 \mathrm{~min}$. Ascorbic acid was used as standard. The absorbance of the resulting mixture was measured at $518 \mathrm{~nm}$ and converted to percentage.

Percent antioxidant activity was calculated using the formula:

$\%$ antioxidant activity $=\frac{\text { Absorbance of control }- \text { Absorbance of test }}{\text { Absorbance of control }} \times 100$

\section{Ferric reducing antioxidant power}

Ferric reducing antioxidant power was determined as described by Hinneburg et al. [20]. One millilitre hexane or aqueous fractions $(0.1 \%)$ of $T$. daniellii leaf was mixed with $2.5 \mathrm{ml}$ phosphate buffer $(0.2 \mathrm{M}, \mathrm{pH} 6.6)$ and $2.5 \mathrm{ml} 1 \%$ potassium hexacyanoferrate. After $30 \mathrm{~min}$ incubation at $50^{\circ} \mathrm{C}$, $2.5 \mathrm{ml} \mathrm{10 \%}$ trichloroacetic acid was added, and the mixture centrifuged at $3000 \mathrm{rpm}$ for $10 \mathrm{~min}$. The supernatant $(2.5 \mathrm{ml})$ was mixed with $2.5 \mathrm{ml}$ water and $0.5 \mathrm{ml}$ of aqueous $0.1 \% \mathrm{FeCl}_{3}$. The absorbance was read at $700 \mathrm{~nm}$. Standard ascorbic acid was used to plot the calibration curve. 


\section{Statistical analysis}

Statistical analysis was carried out using SPSS for Windows; SPSS Inc. Chicago Standard Version 17.0. Statistical comparison was performed using Student $\mathrm{t}$ test. $\mathrm{P}<0.05$ was considered to be statistically significant. Data were expressed as mean \pm SEM

\section{Results and discussion}

T. daniellii leaves are used by local food industry in West Africa as an organic wrapper for some foods including rice and bean pudding. Physical observation by consumers had shown that $T$. daniellii leaves influences the color and taste of foods processed and packaged with it.

From this present study, data showed that $T$. daniellii leaves contained flavonoids, polyphenols, alkaloids and saponins (Table 1). This indicated that $T$. daniellii leaves could serve as a source of bioactive compounds with nutraceutical benefits against several degenerative diseases. Phytocompounds are currently being harnessed by food industry as a source of important food condiments or nutraceutical agents [21,22]. Previous study had shown that bright colors in plants might be attributed to the presence of polyphenols and flavonoids [23]. This could account for the orange-like color that $T$. daniellii leaves impact on some foods.

In addition, flavonoids possesses anti-allergic, anti-inflammatory [24] and anti-cancer properties [25]. Flavonoids and polyphenols have also been reported to serve as potent antioxidant and free radical scavengers capable of protecting the body against oxidative stress-induced cellular damage [26,27]. Investigation of alkaloid bioactivity showed that it possesses antimicrobial, antimalarial and anti-inflammatory properties [28,29]. Saponins are known to reduce glucose uptake and cholesterol at the gut which indicates that it possesses hypocholesterolemic effects [30].

Further study showed that the aqueous fraction of $T$. daniellii leaves contained higher polyphenol and flavonoid contents than the hexane fraction (Table 1). This suggested that majority of the polyphenols and flavonoids present in $T$. daniellii leaves may be structurally polar in nature. Previous study had shown that some polyphenols and flavonoids are structurally polar with antioxidant activity [31,32].

This present study also suggested that the polyphenols and flavonoids could account for the color and flavor introduced into foods wrapped with $T$. daniellii leaves. Perhaps this could be due to processing of some foods like bean pudding which requires aqueous solution [33]. Water can extract polar phytochemicals present in $T$. daniellii leaves into food wrapped with it. However, it has also been reported that the fragrance in food wrapped with $T$. daniellii leaves might be due to the presence of essential oil from T. daniellii leaves [14].

Table 1: Phytochemical contents in T. daniellii fractions

\begin{tabular}{llc}
\hline Phytochemicals & \multicolumn{2}{c}{ T. daniellii leaves } \\
& Hexane fraction & Aqueous fraction \\
\hline Polyphenols (mg\% gallic acid) & $0.23 \pm 0.3^{\mathrm{a}}$ & $0.41 \pm 0.1$ \\
Flavonoids (mg \% quercetin) & $0.11 \pm 0.1^{\mathrm{a}}$ & $0.28 \pm 0.1$ \\
Saponins (\%) & \multicolumn{2}{c}{$6.5 \pm 0.5$} \\
Alkaloids (\%) & \multicolumn{2}{c}{$49.3 \pm 1.4$} \\
\hline
\end{tabular}

a-indicates statistically significant different from hexane fraction at $\mathrm{P}<0.05$

Investigation of the antioxidant activity of $T$. daniellii leaves showed that the aqueous fraction exhibited a significantly $(\mathrm{P}<0.05)$ higher DPPH radical scavenging activity than the hexane fraction at $100-500 \mathrm{mg} / \mathrm{ml}$ (Fig. 1). This indicated that the aqueous fraction of $T$. daniellii leaves contained 
more phyto-antioxidant compounds than the hexane fraction. This seems to be in consonance with higher phytochemical content in aqueous leaf fraction than the hexane leaf fraction. DPPH radicals had shown that it react with appropriate reducing agent with concomitant stoichiometric color loss depending on the number of electrons taken up [34]. Furthermore, previous study had shown that most antioxidant compounds are structurally polar. This is due to presence of the hydroxyl groups present in the polyphenol and flavonoid ring with antioxidant properties [35].

Further investigation showed that aqueous fraction of $T$. danielli leaves exhibited a significantly $(\mathrm{P}<0.05)$ higher ferric ion reducing potential than hexane leaf fraction (Table 2$)$. This observation supported the previous claim that aqueous fraction of $T$. danielli leaves contained more antioxidant compounds than hexane fraction. This might be due to the hydrogen donating potentials of polyphenols and flavonoids as well as the basic structural orientation of the functional groups present. It had also been reported that the ring orientation of compounds determines the extent at which a hydroxyl group donates hydrogen atom to free radicals as well as the capacity of the antioxidants to support an unpaired electron [36].

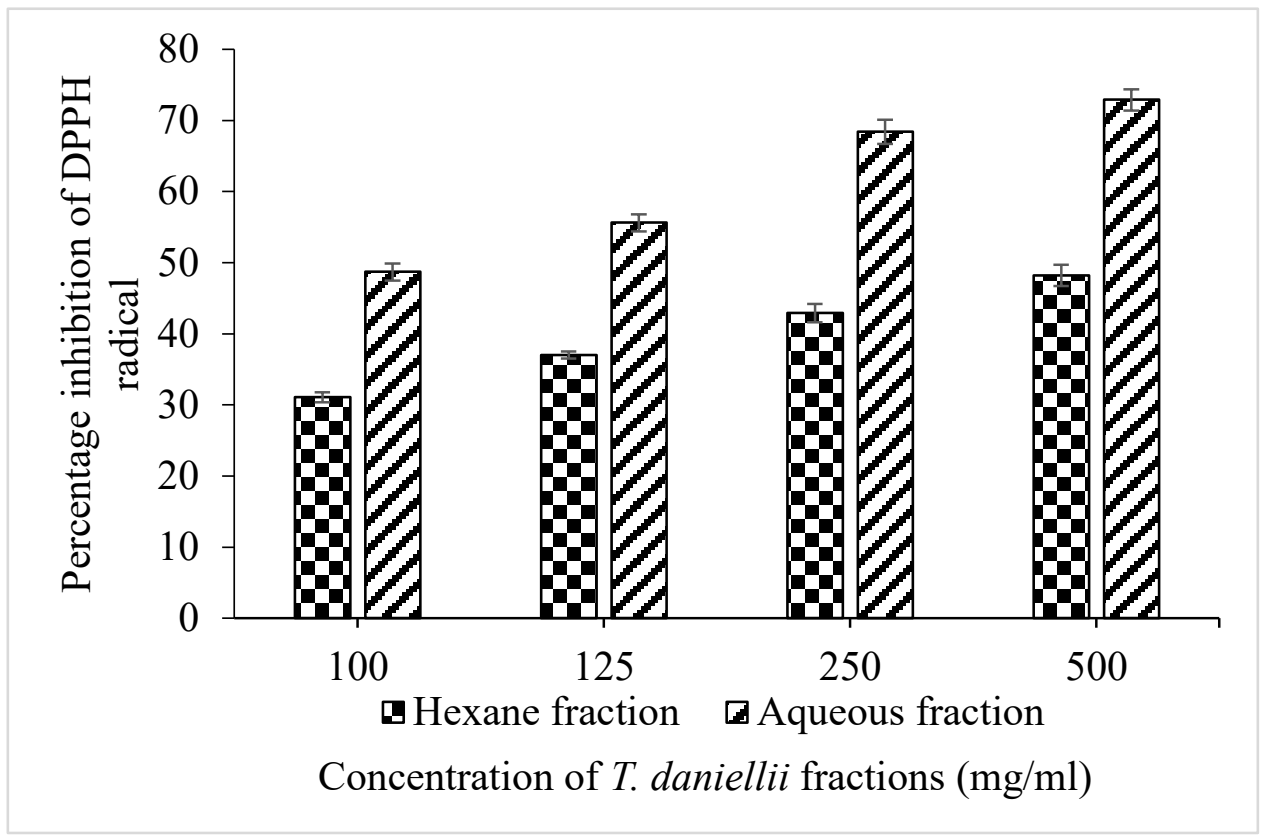

Figure 1: DPPH radical scavenging activities of aqueous and hexane fractions of Thaumatococcus daniellii leaves

Table 2: Ferric reducing antioxidant potential (FRAP) of T. daniellii leaf fractions

\begin{tabular}{ccc}
\hline \multirow{2}{*}{ Parameter } & \multicolumn{2}{c}{ T. daniellii leaves } \\
& Aqueous fraction & Hexane fraction \\
\hline FRAP $\left(\mathrm{mg}^{2}\right.$ ascorbic acid equivalent $)$ & $0.49 \pm 0.1^{\mathrm{a}}$ & $0.27 \pm 0.0$
\end{tabular}

a-indicates statistically significant different from hexane fraction at $\mathrm{P}<0.05$

\section{Conclusion}

This study indicated that $T$. daniellii leaves possessed phytochemicals with potential antioxidant activity and perhaps the phyto-compounds might have contributed to color and flavour introduced into foods wrapped with it. In addition, data suggested that aqueous fraction of $T$. daniellii leaves contained higher antioxidant compounds than the hexane fraction. 


\section{Acknowledgements}

The authors sincerely appreciates Babcock University administration for their support and also Mr. A.J. Ayinde and Mrs. C. Anyasor, Babcock University for the technical assistance they provided during this course of this research and preparation of the manuscript.

\section{References}

[1] S.K. Ansari, G. Jaiswal, Status of antioxidants in rheumatoid arthritis patients using nonsteroidal anti-inflammatory drugs. J. Evid. Based Med. Health 3(2016) 89-93.

[2] S.B. Nimse, D. Pal, D. Free radicals, natural antioxidants, and their reaction mechanism. Royal Society Chem. Adv. 5 (2015) 27986-28006.

[3] A.S. Eboh, Biochemistry of free radicals and antioxidants. Scholars Acad. J. Biosci. 2 (2014) $110-118$.

[4] V. Mercedes, B.F Navarro, Antioxidant capacity of food. Free Rad. Antiox. 6 (2016) 1-12.

[5] S. Saikat, C. Raja, C. Sridhar, Y.S.R. Reddy, D. Biplab, D. Free radicals, antioxidants, diseases and phytomedicine: current status and future prospect. Int. J. Pharma. Sci. Rev. Res. 3 (2010) 91-100.

[6] A. Shukla, R. Tyagi, V. Swati, R.K. Shukla, Total phenolic content, antioxidant activity and phytochemical screening of hydroalcoholic extract of Casearia tomentosa leaves. J Chem and Pharma Res 8(2016) 136-141.

[7] S.C.O. Makinde, C.K. Taiwo, C.K. In situ population evaluation of Thaumatococcus danielli (Benth). Asset Int. J. 1(2004):75-80.

[8] S.O. Yeboah, T.H. Hilger, J. Kroschel, Thaumatococcus danielli (Benth): A natural sweetener from the rain forest zone in West Africa with potential income generation in small scale farming. J. Applied Sci. 6(2003) 854-859.

[9] O.G.E. Arowosoge, L. Popoola, Economic analysis of Thaumatococcus daniellii (Benn.) benth. (Miraculous berry) in Ekiti State, Nigeria. J. Food Agri. Environ. 4(2006) 264-269.

[10] E.C. Zemanek, B.P. Wasserman, B.P. Issues and advances in the use of transgenic organisms for the production of thaumatin, the intensely sweet protein from Thaumatococcus danielli. Crit. Rev. Food Sci. Nutr. 35(1995) 455-466.

[11] T.O.A. Adeyemi, O.D. Idowu, R.O. Ogboru, W.E. Iyebor, E.A. Owoeye, Phytochemical screening, nutritional and medicinal benefits of Thaumatococcus danielli Benn (Benth.) Int. J. Appl. Res. Technol. 3(2014) 92-97.

[12] I.C. Onwueme, B.E. Onochie, E.A. Safowora, Cultivation of Thaumatococcus daniellithe sweetener. World Crops, 1979.

[13] B. Thorn, Chefs find banana leaves appealing: natural food wrapper, an authentic way to showcase tropical, ethnic foods. Nations Restaurant News, November 8, 2004.

[14] A.B. Ojekale, S.C.O. Makinde, O. Osileye, Phytochemistry and anti-microbial evaluation of Thaumatococcus danielli, Benn. (Benth.) leaves. Nig. Food J. 25(2007)176-183.

[15] K. Ghasemi, Y.D. Ghasemi, M.A. Ebrahimzadeh Antioxidant activity, phenol and flavonoid contents of 13 citrus species peels and tissues. Pak. J. Pharm. Sci., 22(2009) 277-281.

[16] A.A.L. Ordoñeza, J.D. Gomez, M.A. Vattuone, M.1. Isla, Antioxidant activities of Sechium edule (Jacq.) Swartz extracts. Food Chem. 97(2006) 452-458.

[17] D.E. Okwu, C. Josiah, Evaluation of the chemical composition of two Nigerian medicinal plants. Afr. J. Biotechnol. 5(2006) 357-361.

[18] J.C. Onyilagha, S. Islam, Flavonoids and other polyphenols of the cultivated species of the genus Phaseolus. Int. J. Agric. Biol. 11(2009) 231-234. 
[19] L.I. Mensor, F.S. Menezes, G.G. Leitao, A.S. Reis, T.C. Santos, C.S. Coube, S.G. Leitao, Screening of Brazilian Plant Extracts for Antioxidant Activity by the Use of DPPH Free Radical Method. Phytotherapy Res. 15(2001) 127-130.

[20] I. Hinneburg, D.H.J. Dorman, R. Hiltunen, R. Antioxidant activities of extracts from selected culinary herbs and spices. Food Chem. 97(2006):122-129.

[21] V. Yadav, L. Sharma, B. Thomas, M.A. Hail, M.A. An overview on nutraceuticals as pharmaceutical agents. Adv. Biores. 3(2012) 113-128.

[22] A. Subramoniam, Present scenario, challenges and future perspective in plant based medicine development. Annals Phytomed. 3(2014) 31-36.

[23] J. Dai, R. Mumper, Plant phenolics: extraction, analysis and their antioxidant and anticancer properties. Molecules 15(2010) 7313-7352.

[24] R.R.R. De Sousa, K.C.S. Queiroz A.C.S., Souza S.A. Gurgueira, A.C. Augusto, Phosphoprotein levels, MAPK activities and NFkB expression are affected by fisetin. J. Enzyme Inhibition Med. Chem., 22(2007) 439-444.

[25] G.N. Anyasor, K.O. Ogunwenmo, O. Oyelana, B. Akpofunure, Phytochemical constituents and antioxidant activities of aqueous and methanolic stem extracts of Costus afer Ker Gawl (Costaceae). Afri. J. Biotechnol. 91(2010) 4880-4884.

[26] O.P.C. Ugwu, O.F.C., Nwodo, P.E. Joshua, A. Bawa, E.C. Ossai, Phytochemical and acute toxicity studies of Moringa oleifera ethanol leaf extract. Int. J. Life Sci. Biotechnol. Pharma. Res. 2(2013) 66-71.

[27] G.N. Anyasor, F.D. Onajobi, O. Odutola, O. Adebawo, Phytochemical constituent in hexane fraction of costus afer ker Gawl. Stem. Vedic Res. Int. Phytomed. 2(2014) 66-72.

[28] D.E. Okwu, M.E. Okwu, M.E. Chemical composition of Spondias mombin Linn. Plants parts. J. Sustain. Agri. Environ. 6(2004) 40-147.

[29] A. Gurib-Fakim, Medicinal plants: traditions of yesterday and drugs of tomorrow. Mol. Aspect Med. 27(2006) 1-93.

[30] A. Ali, Screening of phytochemical compounds and toxic proteinaceous protease inhibitor in some lesser-known food based plants and their effects and potential applications in food. Int. J. Food Sci. Nutr. Eng. 2(2012) 16-20.

[31] P.S. Norma R. Saul, A.C. Luis, I.E. María, J.O. José de, Total phenolic, flavonoid, tomatine, and tomatidine contents and antioxidant and antimicrobial activities of extracts of tomato plant. Int. J. Anal. Chem. 2015 http://dx.doi.org/10.1155/2015/284071

[32] W. Poontawee, S. Natakankitkul, O. Wongmekiat, O. Enhancing phenolic contents and antioxidant potentials of antidesma thwaitesianum by supercritical carbon dioxide extraction. J. Anal. Meth. Chem. 2015 http://dx.doi.org/10.1155/2015/956298

[33] J.N. Nwosu N.C. Onuegbu, C.C. Ogueke, N.O. Kabuo, G.C. Omeire, Acceptability of moinmoin produced from blends of african yam bean (Sphenostylis stenocarpa) an cowpea (Vigna unguiculata). Int. J. Curr. Microbiol. Appl. Sci. 3(2014) 996-1004.

[34] E.N. Hristea, T.C. Miron, P. Gabriela, H. Mihaela, C. Titus, C. Reaction of 2, 2-Diphenyl-1picrylhydrazyl with $\mathrm{HO}, \mathrm{O}^{2-}, \mathrm{HO}^{-}$, and $\mathrm{HOO}^{-}$Radicals and Anions. Int. J. Mol. Sci. 7(2006) $130-143$.

[35] T. Prashant, K. Bimlesh, K. Mandeep, K. Gurpreet, K. Harleen, Phytochemical screening and extraction: a review. Int. Pharma. Sci. 1(2011) 98 -106.

[36] M.G. Miguel, Anthocyanins: antioxidant and/or anti-inflammatory activities. J. Appl. Pharma. Sci. 1(2011) 7-15. 